М.В. Михайлова (Москва, Россия), Н.М. Ботнаренко (Ивано-Франковск, Украина)

Человечность - мера всех вещей

Ігор Козлик. Професія крізь призму людяності. Івано-Франківськ: Симфонія форте, 2016. 228 с.

M.V. Mikhailova (Moscow, Russia), N.M. Botnarenko (Ivano-Frankivsk, Ukraine)

\title{
Humaneiness is the Measure of All Things
}

Ігор Козлик. Професія крізь призму людяності. Івано-Франківськ: Симфонія форте, 2016. 228 с.

«Человек тот, кому дороже и выше всего звание человека, человек “по профессии", словом - писатель...» - так определил основное качество писателя А.А. Блок. Близко этому высказыванию название книги профессора, доктора филологических наук Игоря Владимировича Козлика «Профессия сквозь призму человечности», который именно гуманистической наполненностью измеряет филологическое призвание. Основная интенция его книги заложена, как видим, в заглавии. Она посвящена воспоминаниям, размышлениям о выдающихся ученых, литературоведах, которых автор знал лично или узнавал их, читая их труды. Книга в некотором роде обобщает опыт определенного отрезка жизни, когда человек, утвердившись в своей деятельности, размышляет над своей профессией и находит ракурс оценки: человеческий фактор.

Книге предпослан эпиграф: стихотворение Бориса Божнева «Неблагодарность - самый черный грех...». И это не случайно, поскольку именно «благодарность» является мерой человеческого достоинства, по мнению автора. Собственно этот посыл и объединяет его кинодокументалистику, которой он занимается уже несколько лет, посвящая фильмы своим учителям, духовным наставникам и друзям. В его багаже уже имеются следующие ленты: «Марк Теплинский - учитель, ученый, человек» (2012), «Глазами Другого: Марк Теплинский и Владимир Матвиишин» (2013), «Оставаться человеком, или Не дать умереть памяти» (2014, о жизни и деятельности доктора технических наук, профессора Петра Ивановича Мельника), «Академик Дмитрий Наливайко» (2016) ${ }^{1}$. И книга «Профессия сквозь

${ }^{1}$ Cм.: www.youtube.com/channel/UCz-W0WLgdykbS4s8MOTtuaQ 
призму человечности» является как бы продолжением того, что было начато в этих работах.

Открывается издание авторским предисловием - «О замысле этой книги», в котором кратко говорится о цели данной работы. «Я прежде всего литературовед, то есть тот, кто работает в сфере науки о литературе, - пишет И.В. Козлик, обращаясь к читателям. - Так сложилось. И поэтому то, о чем пойдет речь далее, будет касаться в первую очередь этой гуманитарной науки и тех, кто связал свою жизнь с ней <..>. Жизнь и деятельность ученого воплощаются не только в его научных исследованиях (статьях, монографиях), посвященных собственно предмету его профессиональной деятельности. Другая их сторона связана с чисто человеческим измерением профессионального бытия, с пространством живого общения с теми людьми, с кем на различных этапах связаны судьбоносные поступки выбор жизненного пути, профессии как дела жизни, а позже - поддержка и стимулирование в личностном и профессиональном становлении. Ведь всю нашу жизнь нас кто-то окружает, сопровождает, иногда опекает, да и само пребывание в научной сфере, причем с самого начала, неразрывно связано с конкретными фигурами, а среди них - с теми, кто для каждого из нас олицетворяет саму сущность конкретной культуротворческой деятельности» (стр. 7). И далее он делает методологическое обобщение из сказанного: «<... именно человеческое измерение специальности не является второстепенным или факультативным. В морально-психологическом смысле оно является базовым» (там же).

В рецензируемой книге собраны научные статьи, воспоминания, выдержки из писем. Она состоит из трех разделов: «Литературоведческие практики в плоскости методологической рефлексии», «Профессиональное бытие в индивидуальном пространстве межличностного общения (воспоминания, размышления, фрагменты эпистолярия)», «В отголоске специальности». Нам не кажутся эти заголовки удачными. Они грешат наукообразием и несколько затушевывают тот эмоциональный порыв, который явно двигал автором при отборе имен. Но, наверное, профессору показалось, что так его труд приобретает филологическую весомость... Имеет право...

В первой части раскрывается существо научных концепций известных ученых-литературоведов - М.В. Теплинского (1924-2012), Ю.И. Султанова (19482003), А.В. Чичерина (1899/1900-1989), М.М. Гиршмана (1937-2015), Н.Х. Копыстянской (1924-2013), Р.Т. Громяка (1937-2014), С.Д. Павлычко (1958-1999). При их анализе И.В. Козлик опирается на системный подход, который определяет следующим образом: он дает возможность осуществлять «определенную последовательность действий (операций), правила их применения, призванных решить определенную задачу, а их схематизация уже сама по себе открывает путь к определенной познавательной информации» (стр. 50). При таком подходе ничто не может «выпасть» из поля зрения исследователя. Но важно, что в каждом индивидуальном случае И.В. Козлик находит «изюминку», т. е. то, что составляет уникальность каждого крупного ученого. У М.В. Теплинского, своего наставника и научного руководителя, И.В. Козлик выделил базовые параметрические характеристики его гносеолого-эвристической деятельности, указал на его эвристический опыт. Автор оперирует понятием «академичность», которое оказывается той категорией, которая наиболее адекватно характеризует научный метод ученого. В отношении известного украинского ученого-методиста Ю.И. Султанова И.В. Козлик предложил вариант семиотической проекции его творчества. А говоря о Г.П. Щедровицком, выдвинул на первый план системомыследеятель- 
ностную (СМД) методологию, которой тот руководствовался при преподавании литературы. Различные уровни «теоретической доктрины литературного стиля» он обнаружил у профессора А.В. Чичерина (стр. 30-47). При этом, обратив внимание на точки пересечения научных открытий А.В. Чичерина и В.В. Виноградова, М.М. Бахтина, Ю.Н. Тынянова, Ю.М. Лотмана, А.И. Белецкого и др., автор делает важный вывод о том, что «все они были сформированы в лоне органического филологического подхода, которому присуще восприятие художественной литературы в ее онтологической самости (имманентности) как искусства слова с ориентацией на сквозную литературоведческую проблематику» (стр. 45). Такой же подход применен и к анализу проблемы целостности в разработанной профессором М.М. Гиршманом теории (стр. 57-67). Были важны для автора книги и методологические наработки профессора Н.Х. Копыстянской (стр. 69-80), сосредоточившейся на изучении жанровой природы произведения, когда он писал докторскую диссертацию «Философская лирика: дифференциация видов и жанровая интеграция» (2008). Тем не менее, однако, к проблеме жанра каждый из литературоведов подошел по-своему. Так, Н.Х. Копыстянская исходила «из традиционных внутренних сфер историко-литературной науки», а он отталкивался от «внелитературной плоскости общей методологии Г.П. Щедровицкого и философской герменевтики Г.-Г. Гадамера» (стр. 69-70). При этом автор отдает должное открытиям и итоговым размышлениям Н.X. Копыстянской, дальнейшее функционирование которых в работах учеников и коллег по литературоведческому цеху и становится «настоящим продолжением жизни ученого» (стр. 70).

Основательным и развернутым представляется подраздел «Профессор Р.Т. Громяк: методологические параметры научной деятельности ученого» (стр. 81-110). И.В. Козлик убедительно аргументирует свое утверждение, что основой организационной работы Р.Т. Громяка стало «понимание неделимости науки как культуротворческого феномена» (стр. 83) и что для этого ученого особенно значимыми были именно этическое измерение профессии и проблема воспитания современного специалиста. Автор книги также рассматривает и факторы, повлиявшие на становление и формирование личности самого Р.Т. Громяка как ученого и организатора науки, в которой большую роль сыграли компаративистские исследования.

В наследии С.Д. Павлычко И.В. Козлик выделил работу «Методологическая ситуация в современном украинском литературоведении» (стр. 111-115), в которой было обращено внимание на ряд устаревших гносеолого-эвристических парадигм мышления, еще функционирующих в современном литературоведении, но с преодолением которых связана перспектива развития украинского литературоведения в целом. И.В. Козлик убежден, что «сам факт периодического появления публикаций на эту тему не только свидетельствует о возможности возникновения внимания украинских литературоведов к проблемам методологии и теоретических основ собственной научной деятельности», что постепенно определяет не только «круг их дальнейшего компетентного обсуждения, но и артикулирует и объективирует те мировоззренческие тенденции, на сосуществовании и столкновении которых реально функционирует современное украинское литературоведческое сознание» (стр. 114-115).

Анализ научных концепций таких знаковых в украинской науке личностей, как М.В. Теплинский, Ю.И. Султанов, А.В. Чичерин, М.М. Гиршман, Н.Х. Копыстянская, Р.Т. Громяк, С.Д. Павлычко, подтолкнул создателя рецензируемой монографии к мысли о традициях в развитии литературоведческой науки как одной из форм проявления закона культурной преемственности, что так или иначе определяет феномен 
научной школы, в которой вопрос о личности ученого как носителе определенной системы ценностей, передачи научного опыта стоит особенно остро.

Это размышление логично подводит читателя к разделу «Профессиональное бытие в индивидуальном пространстве межличностного общения (воспоминания, размышления, фрагменты эпистолярия)», построенному в форме мемуаров. Это воспоминания об ученых-литературоведах, которых автор знал лично и которые оставили значительный след в его жизни, будучи носителями определенной культурной традиции. Здесь читатель может познакомиться с жизнью и научной деятельностью члена-корреспондента НАН Украины Нины Евгеньевны Крутиковой (1912-2008), работавшей в Институте литературы имени Т.Г. Шевченко НАНУ в Киеве, с оппонентом по кандидатской диссертации автора доктором филологических наук, профессором Леонидом Генриховичем Фризманом из Харьковского государственного педагогического университета имени Г.С. Сковороды, с польским профессором Базилем Яновичем Бялокозовичем (1932-2010) и Романом Теодоровичем Громяком, с которыми автора связывали теплые отношения на протяжении долгих лет. Особой теплотой проникнуто эссе о кандидате филологических наук, доценте кафедры мировой литературы Прикарпатского национального университета имени В. Стефаника Мирославе Медицкой (1978-2010), жизнь которой трагически оборвалась так рано. Особенно привлекательны в этом разделе цитаты из писем и стихов, комментарии к которым окрашены личностным лирическим чувством.

Также в форме воспоминаний и размышлений написан последний раздел книги - «В отголоске специальности». Название раздела говорит само за себя: отголосок, т. е. «отраженные звуки, доносящиеся издалека». Этот раздел посвящен не научной деятельности ученых, а их творческим интересам. Так, автор анализирует первый сборник стихов своего покойного друга, кандидата педагогических наук Юрия Ибрагимовича Султанова «Алхимия виртуальных игр» (Киев, 2001). Также здесь читатель может познакомиться с жизнью и литературным творчеством яркой и неординарной личности - известным донецким, а позже ивано-франковским врачом-дерматологом, доктором медицинских наук, профессором Леонидом Михайловичем Гольдштейном (1919-2005), сумевшим объединить вокруг себя единомышленников, связанных особой атмосферой культурного сотрудничества.

Концепция книги И.В. Козлика перекликается с суждением Григория Сковороды, который считал, что главная задача в воспитании молодого человека заключается в умении научить его благодарности. Именно это чувство делает «человека человеком». Поэтому книга адресована не только ученым, коллегам, а прежде всего молодому поколению, которое может вобрать в себя самое ценное - опыт и мудрость старших. И некоторая разножанровость представленных материалов становится ее плюсом, так как представляет этот опыт во всем его объеме и многообразии. Сам автор признается, что тексты первоначально появились «независимо друг от друга и при разных обстоятельствах», но оказались в итоге «объединены сквозным сюжетным вектором» - целостью накопленного опыта, который, как он подчеркивает, «по своему смысловому наполнению выходит за пределы $<\ldots>$ частного существования и может вызвать интерес у тех, кто, совершая свой жизненный выбор, собирается связать (или уже связал) свою жизнь с наукой о литературе» (стр. 8). Нельзя не присоединиться к этим его словам! 
Мария Викторовна Михайлова,

доктор филол. наук

профессор

филологический факультет

МГУ имени М.В. Ломоносова

Наталия Михайловна Ботнаренко,

канд. филол. наук

преподаватель

Прикарпатский национальный университет имени Василя Стефаника

(Ивано-Франковск, Украина)
Maria V. Mikhailova,

Doctor of Philology

Professor

Philological Faculty

Lomonosov Moscow State University

mary1701@mail.ru

Natalia M. Botnarenko,

$\mathrm{PhD}$

Lecturer

Vasyl Stefanyk Precarpathian National University (Ivano-Frankivsk, Ukraine) 